\title{
Questionable Reform: The Adoption of the Double-Entry Bookkeeping and Accrual Basis Accounting System in Korea*
}

\author{
Tobin Im**, Hyunkuk Lee***, and Dongwan Lim****
}

\begin{abstract}
This study examines the factors that influence human vulnerability to natural disasters by focusing on the seismic evaluation of school buildings in Korea. Since natural disasters such as an earthquake often do not take people's lives directly, but rather indirectly through the destruction of physical structures, seismic reinforcement of school buildings may reduce the vulnerability of their occupants by strengthening structures to withstand such disasters. Disaster mitigation measures are implemented within a state; however, little is known about how they are distributed when the physical properties of structures are taken into account. This paper analyzes a panel data based on the structural properties of school buildings in eight different provinces between 2011 and 2015 using a logistic regression model. The results show that factors identified in cross-country studies, such as economic capacity and political factors, still have influence on earthquake preparedness at the state level, even when the physical properties of structures or technical factors are considered.
\end{abstract}

Keywords: human vulnerability; natural hazards; seismic evaluation; school buildings

* This study was supported by a National Research Foundation of Korea Grant from the Korean Government (NRF-2017S1A3A2065838).

** Tobin Im is a professor in the Graduate School of Public Administration at Seoul National University. E-mail: tobin@snu.ac.kr.

*** The corresponding author, Hyunkuk Lee is an assistant professor at Daejeon University. E-mail: hklee@dju.kr.

**** Dongwan Lim is an associate professor at Dankook University. E-mail: sum2@ dankook.ac.kr.

Manuscript received February 10, 2018; out for review February 28, 2018; review completed April 11, 2018; accepted April 13, 2018.

The Korean Journal of Policy Studies, Vol. 33, No. 1 (2018), pp. 57-80.

(C) 2018 by the GSPA, Seoul National University 


\section{INTRODUCTION}

Government debt and resource waste are significant obstacles to enhancing the performance of service delivery in the public sector. Since the founding of the Republic of Korea, its government bureaucracies have often been accused of reckless spending and fiscal irresponsibility and of taking for granted the coffers that consist of taxpayer's contributions. But until recently, there was little accurate information available about the debts of government agencies. Nobody, including the ministers in charge or even accounting experts, could discern the real financial status of government organizations, and this shortcoming in the flow and quality of information was directly related to a fragmented and inconsistent accounting system throughout the public sector. For instance, relevant information regarding government finance has been partially and separately managed by different ministries and agencies, thereby leading to significant difficulties in communication regarding the financial status of various organizations within the public sector as a whole.

The Ministry of Finance, the office of primary responsibility for government-wide financial matters, has long claimed a privileged position in the information management process, but in recent years National Assembly members as well as a growing numbers of nongovernmental organizations (NGOs) have been putting pressure on the government to fully disclose public finance information, as the government's privileged access to government-guaranteed funds and the lack of oversight as to how these same funds are spent has created a great deal of doubt among citizens. Government bureaucrats have not had to pay as much attention to their expenses as managers operating in the private sector due to this lack of transparency have had to, a perk they enjoyed and were reluctant to give up.

Here we attempt to address the question of how to make the financial activities of a government more responsible. The public administration literature has recommended a reinforcement of external control by strengthening the roles of parliament, mass media, and NGOs. But increasing the monitoring power of agents external to the expenditure process will yield greater accountability only if the activities that they are monitoring are in themselves amenable to consistent evaluation. Thus, in addition to strengthening the role of watchdogs, it is necessary to ensure that the accounting tools themselves produce financial information that can be used to hold the bureaucracy accountable.

Before 2009, the Korean government used a single-entry, cash basis accounting system for its bookkeeping. More suitable for tracking the funds of a small-sized business than a complex government bureaucracy, this system makes it difficult for everyone, including those who work inside the bureaucracy itself, to ascertain the 
real status of the budget at a given time from the official budget documents alone. This lack of comprehensiveness in turn produces a skewed picture of debts and leads to resource waste, problems that a more comprehensive accounting system might prevent.

Beginning in the 1980s, most of the major developed countries across the world embarked on accounting modernization reforms, though such initiatives were largely confined to the United Kingdom, New Zealand, Australia, Canada, and the United States, all of which have shown a marked preference for the philosophy loosely defined as New Public Management (NPM) (Lim \& Jong, 2007; Lim, 2007). NPM came to be regarded by Korean reformers and scholars as the means by which to bring enhanced efficiency and accountability to their outdated system. Thus a plan was introduced to adopt the double-entry, accrual basis accounting system in Korea.

After a long period of discussion and examination of possible reforms and their projected effects, in 1998 Bucheon was the first local government selected to implement the new system of accounting as part of a pilot project. Five years later, in 2003, Bucheon was also lauded for its success in instituting accounting reforms at an academic conference hosted by the Comparative International Governmental Accounting Research network.

Our study consists of three sections. In the first, we outline the historical situation in Korea that gave rise to the need to modernize accounting practices. This first section introduces us to both the internal forces as well as the external actors that pressed for accounting reform in Korea and played a major part in bringing it about. It also briefly recalls the effects of the Asian economic collapse of 1997 and particularly the impetus the crisis provided for reforming Korea's accounting system. In the secondly, we provide an overview of how the reforms were carried out in Korea, who the key actors and groups were, and what the unique Korean contributions to the process were. In the last section, we consider the case of Bucheon and outline the major benefits of the accounting reforms implemented in that pilot city. Here, we emphasize the wealth of analytical accounting information now available for the city as a result of the reforms. We close our investigation with a number of policy suggestions on how the reforms, though largely successful, might be modified to allow governments to better take advantage of other context-based peculiarities of the Republic of Korea and its public sector. 


\section{FINANCIAL PRESSURE AND THE GLOBAL CONTEXT OF ACCOUNTING REFORM}

In the 1970s, numerous developed and developing countries were facing financial pressures that had resulted from overspending and deterioration of the external trade balance, which, in turn, subsequently led to economic slumps. As one of the attempts to solve these kinds of economic and financial problems, many countries began introducing various reform programs to their public sectors.

Since the 1980s, reform in line with the so-called NPM became a global trend, mostly with OECD countries, including the United Kingdom, Australia, New Zealand, Canada, and the United States, embarking on public sector reforms (Pollitt \& Bouckaert, 2004). The debatable nature of the true effects of these reforms notwithstanding, they have shifted emphasis from process-oriented to result-oriented accountability and thus have also forced budgeting and accounting changes in public sector organizations to take account of this new emphasis (Hood, 1991, 1995).

Figure 1. Accounting Basis for Annual Financial Reports in OECD Countries

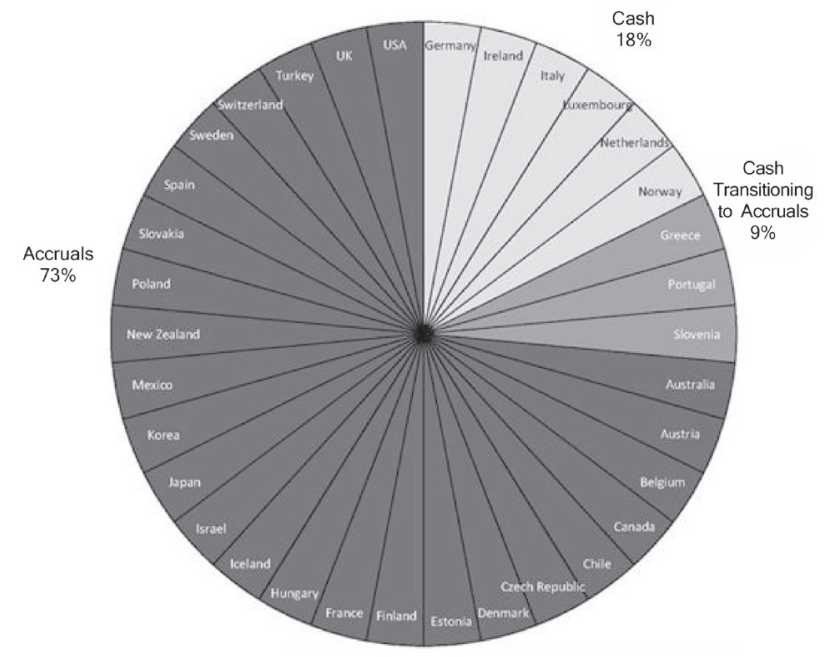

Source: OECD, 2017, p. 13.

The budgeting and accounting system is one of the most difficult subsystems within the public sector to which to introduce these kinds of reforms, and many countries are reluctant to adopt them. These types of reforms are intended to 
enhance the efficiency of resource allocation while ensuring the technical efficiency of bottom-up decision making and to introduce tools for measuring the performance of result-oriented budget systems, and for creating multiyear budget systems designed to enable multiterm financial planning. The OECD's first accruals survey in 2003 reported that $24 \%$ of countries use accrual basis accounting; the 2016 survey shows that the ratio has escalated to $73 \%$.

Table 1. Accounting System Reforms in Major OECD Countries

\begin{tabular}{|c|c|c|}
\hline Country & Year & Length of Time to Effect Reform \\
\hline Australia & $1990 s$ & $\begin{array}{l}\text { Australia completed its transition to accrual budgeting and ac- } \\
\text { counting in about } 10 \text { years, as part of a broader set of reforms. }\end{array}$ \\
\hline Canada & mid-1990s & $\begin{array}{l}\text { Canada completed its transition to accrual budgeting and ac- } \\
\text { counting in less than } 10 \text { years. }\end{array}$ \\
\hline Finland & 1998 & $\begin{array}{l}\text { Finland completed its transition to accrual accounting in about } 10 \\
\text { years. }\end{array}$ \\
\hline France & 2001 & $\begin{array}{l}\text { France completed its transition to accrual accounting in about four } \\
\text { years. }\end{array}$ \\
\hline Germany & $\mathrm{n} / \mathrm{a}$ & $\begin{array}{l}\text { Germany has not adopted accrual accounting at the central gov- } \\
\text { ernment level. }\end{array}$ \\
\hline Japan & 2000 & $\begin{array}{l}\text { Japan's central government completed its transition to accrual ac- } \\
\text { counting in five years. }\end{array}$ \\
\hline Korea & 2009 & $\begin{array}{l}\text { Korea's central government completed its transition to accrual ac- } \\
\text { counting in twelve ( }{ }^{*} \mathrm{OECD} \text { report two years) years. }\end{array}$ \\
\hline $\begin{array}{l}\text { New } \\
\text { Zealand }\end{array}$ & 1994 & $\begin{array}{l}\text { New Zealand completed its transition to accrual budgeting and } \\
\text { accounting in six years, as part of a broader set of reforms. }\end{array}$ \\
\hline UK & $1993-2002$ & $\begin{array}{l}\text { The UK completed its transition to resource-based budgeting and } \\
\text { accrual accounting in about } 10 \text { years. }\end{array}$ \\
\hline USA & 1984-1998 & $\begin{array}{l}\text { The Government Accountability Office began requiring audited } \\
\text { agency statements on an accrual basis in } 1984 \text { and began requir- } \\
\text { ing government-wide accrual auditing in } 1998 .\end{array}$ \\
\hline
\end{tabular}

Source: Summarized from OECD, 2017. 
The process of transforming an existing accounting system into a new one is neither easy nor simple. It is an institutional change that can only be successful if all relevant actors and legal entities participate (Scott, 1991). It is especially important that bureaucrats change their attitudes and behavior; even the organizational culture as a whole should be reformed to see the best effects of adopting a new accounting system. Such reforms, moreover, need to be codified through revisions to the national legal code in order for the reform measures to gain traction and to indicate the long-term commitment of the country to the reforms, as this is crucial to effectively transform the accounting system.

In a single-entry bookkeeping and cash basis accounting system, public sector entities are given a budget that is calculated in cash terms; they then proceed to spend the money and keep records of each cash disbursement. Although this accounting method may seem simple, it at least ensures that the organization does not go over or under budget. On the other hand, bureaucrats may attempt to maximize their amount of spending, since they do not need to provide information about the assets. What this means is that as long as the single-entry bookkeeping and cash basis accounting system remain the dominant mode of public sector accounting, it will be hard to identify specific linkages between expenditure and cost or between cost and the desired performance of the agency. By itself, the single-entry bookkeeping and cash basis accounting system offer few incentives for government bureaucrats to uphold maximum levels of efficiency or performance (Pollitt \& Bouckaert, 2004, p. 71).

The double-entry bookkeeping and accrual basis accounting system is able to overcome the shortcomings of the single-entry book system by bringing public accounts closer to the private sector model, under which the way assets are used is fully tracked and performance can be measured. Thus, although this system may also provide perverse incentives for adhering to it, in general, it is expected to promote institutional change that may help governments better utilize financial inputs for various public outputs (Ho \& Im, 2012).

A major reform of the national accounting system has certain costs associated with it. Especially significant in this respect is bureaucrats' resistance to change. Public organizations and their relevant stakeholders as well as actors have to prepare for such a reform; they must change their work routine as well as adopt operational techniques appropriate to the new system. For these specific reasons, there was little intragovernmental motivation to reform the system in Korea, and it was only in the face of calls for global accounting standardization from various international financial organizations such as OECD, IMF, and IFAC and domestic pressures arising from acute economic and financial difficulties following the national financial crisis 
of 1997, not to mention the change of political regimes with a new emphasis on public sector reforms and accountability, that Korea finally made the transition to the new system.

\section{FROM SINGLE-ENTRY CASH BASIS ACCOUNTING TO DOUBLE-ENTRY BOOKKEEPING ACCRUAL BASIS ACCOUNTING}

\section{Starting Point}

Every accounting entity in the South Korean government had used a single-entry bookkeeping and cash basis accounting system until the introduction of the reform. The public corporations were exceptions, as they are similar to private companies. Thus, public corporations were the first to embrace private-sector-style accounting practices. With respect to so-called traditional government organizations in the Republic of Korea, it was not until the city of Bucheon, which is located in a suburb of the capital city and has approximately 850,000 residents, was chosen as a pilot city for testing out the new system that the full range of advanced private sector accounting techniques was introduced. Often playing the role of incubator, local municipal governments in recent years that adopted the new bookkeeping system came to be seen as innovators, enhancing the quality of public service.

Like other local municipalities in Korea, Bucheon had a budget consisting of four accounting entities: the general account; the special account; the trust fund account; and (4) a special account for public enterprises. The first three accounts were reconciled using single-entry cash basis accounting, while the fourth was reconciled using double-entry accrual basis accounting.

Before the reforms, the government accounting system in South Korea was restricted to a simple recording of the execution of the budget, focusing on whether the budget was executed as planned and on tracking any illegal or unfair activities during its execution. In other words, the single objective of the system was to ensure that taxpayers' money was being spent as the National Assembly had initially planned. In the end, however, this single-entry bookkeeping system was not capable of meeting the demands of a legislature and civic groups demanding ever greater accountability for public finance.

\section{Motives}

Korean bureaucrats are often caricatured as eating from the "iron rice bowl," 
which refers to their enjoyment of strong job protection and insulation from external events. This perception is the reason different Korean administrations have introduced various reform programs targeting bureaucratic inertia (Im, 2007). Most of these efforts aim at reforms in personnel administration, but they often fail due to a strong tradition of seniority-based promotions, pay, and job protection.

It is in this context that the accounting system reform began to attract attention from experts. The logic is simple: if the government cannot keep bureaucrats' corrupt and irresponsible organizational culture under control, then it needs to monitor financial operations in detail. It became increasingly more important to adopt more advanced accounting practices, namely, the double-entry bookkeeping accrual basis accounting system, to efficiently keep track of detailed financial information. However, this may make it sound as if the domestic influence was the only force in bringing out the much needed accounting reforms, but there were other influences that led to both the internal and external changes that took place in the Korean public financial sector at that time.

First, certain international organizations, including the OECD, IMF, and IFAC among others, unanimously supported double-entry bookkeeping and accrual basis accounting as the default system of financial reckoning for advanced countries. These organizations are powerful forces in the age of globalization, and each was prepared to press for reforms in countries that had not yet conformed to their views. As already noted, the 2016 OECD accruals survey shows that around three-quarters of OECD countries have adopted accrual accounting by this point (OECD, 2017).

This influence became apparent in Korea when it became the 29th member of the OECD in 1995 and advised to replace its budget and accounting system with the accrual basis system. The Kim Young-sam administration was the first to take accrual basis government accounting into consideration (Pyun, 2017, p. 118). In accordance with the worldwide embrace of NPM, Kim Young-sam, who started his presidency by placing a strong emphasis on reform, began to seriously discuss the possibility of adopting accrual basis corporate accounting methods (Pyun, 2017, pp. 118119). The accounting reform that Korea planned was thus part of a larger package that was to target each field of the economy. In addition to making explicit requests, the OECD also exerted indirect influence through its participation in the International Public Sector Accounting Standards Board (IPSASB).

Secondly, the Asian economic crisis and the devastation visited on the Korean economy proved to be a strong motivation for accounting reform. Beginning in the 1960s, South Korea achieved remarkable economic growth, maintaining a yearly economic growth rate that often broke into the double digits. In 1995, South Korea's trade volume ranked world's 11 th, and the GDP per capita reached over $\$ 10,000$. 
Such rapid economic growth had some side effects; a handful of large conglomerates resulted in a drastic level of inequality, and the banking sector came under the close control of the government. These conglomerates, known as "chaebol" in Korean, were able to grow their businesses extremely fast, with the help of a large number of loans mainly from foreign financial institutions with implicit guarantees from the government.

However, it was only after the 1997 East Asian financial crisis that government officials realized urgency of accounting reform. In November 1997, the Korean government failed to maintain an adequate foreign exchange reserve and had no choice but to ask for a financial bailout from the IMF. As a result, 7 out of the largest 30 companies were bankrupted by the end of 1997 due to the refusal of international lending institutions to roll over their short-term loans. This situation further exasperated the citizens of Korea and provided an additional impetus for undertaking accounting reform.

Following the crisis, GDP per capita dropped sharply to below $\$ 7,000$, and Korea's sovereign credit rating plummeted (Jung, Y.D., 2004). Against this backdrop of economic crisis, reform of the budget accounting system became a must for a financial recovery, which would require a far more efficient use of limited resources and appropriate management of financial deficits and liabilities. Thus, the South Korean government had to adopt systems in both the public and private sector that could meet the international standards endorsed by the IMF (Jung, Y.D., 2004).

Another important factor was the special political situation in Korea at the time. The Democratic Party leader Kim Dae-jung was running for president. Kim had been the opposition leader for his whole life, and he was eager to make a big difference in reform policy and hoped to surpass his predecessors, who also had introduced various reform programs. The need to introduce accrual basis accounting and the promotion of a gradual transition to double-entry bookkeeping was an attractive slogan, which Kim adopted.

After the election, which Kim won, his government pushed ahead with reforms in the business, banking, labor, and public sectors, hoping to resolve the national crisis in the midst of which he took office. Kim's government made the greatest strides in the public sector, where greater transparency and efficiency were high priorities for the administration. By 1999, the full effects of the financial crisis became apparent, and the administration pressed for the full adoption of double-entry bookkeeping and accrual basis accounting system (Lee,2003). 


\section{Process of Implementing the Reform}

The process of transforming a single-entry, cash basis accounting system into a double-entry, accrual basis system is complicated in general, but even more so in the case of public organizations, because it requires multidimensional fundamental changes in the internal operation of such organizations, and bureaucrats are generally reluctant to change the way they work. Therefore, strong political will is necessary to enact a national-level reform of this complexity.

Kim's promise to introduce accrual basis accounting and double-entry bookkeeping garnered widespread support from both domestic and international parties. Soon after reformation began at the local level, the Ministry of Public Administration and Security took charge of overseeing it. The ministry decided to conduct pilot reform projects, and in April 1999, it selected Bucheon in Gyeonggi Province and Gangnam-gu district in Seoul as the first two locations for the experimental reforms (Lee, 2003). ${ }^{1}$ As these initial reforms met with success, more pilot projects were launched. And then, in 2007, the Local Governments Public Finance Act was amended, and all local governments of South Korea adopted double-entry bookkeeping and accrual basis accounting systems. The process was complex, yet success was achieved.

Due to Korea's democratization, the number of NGOs that serve as economic watchdogs has increased. On May 16, 1998, the Citizens' Coalition for Economic Justice (CCEJ), one of the most influential and active NGO in Korea, and more specifically its Committee for Budget Surveillance (CBS), began the process of choosing local governments that would be suitable candidates for the pilot study. On September 14, 1998, Lee Kyung Pil, the president of CCEJ, Yoon Young Jin, the chairman of CBS, Professor Kwon Su Young, CPA Kim Sun Ku, and Moon Kwang Seung, the secretary general, organized a meeting with some mayors and high public officials, including Won Hye-young, the mayor of Bucheon, in order to explain the necessity of introducing double-entry bookkeeping. Reactions to the proposal were mixed, but finally mayor Won Hye Young answered positively and Bucheon was chosen as the first city that would reform its accounting system (Jo, 2003).

Without the mayor's support, the pilot study might not have happened. Normally, politicians are reluctant to change fundamental governance systems because they have already achieved success with these systems and also know how to manipulate them to their benefit. This can be even more so in developing countries with serious

1. In 1998, the introduction of the double-entry bookkeeping system was one of 50 reform plans that Ko Kun, the mayor of metropolitan Seoul, declared the city would undertake. 
levels of corruption. Therefore, it is worth examining why Mayor Won agreed to the pilot study.

Born in 1951, the mayor had been an active participant in the county's democracy movement since the 1970 s - so much so that he was put into prison for his activism by the military dictatorship. As an opposition party member, Won strongly supported the movement to fundamentally reform the existing system. Secondly, Won's experience as a businessman running his own company before being elected as a mayor helped him to see the need to change the city's accounting system. His personal experience in the private sector where the double-entry book keeping system is widely used had revealed the strengths of this new system.

Soon after his inauguration, Mayor Won sought to grasp the financial situation of Bucheon City government before launching his own policies. However, he soon encountered frustration in his efforts to understand it from a private-sector CEO's perspective. Because the city used a single-entry accounting system, it took him more than two months just to get a clear idea of the city's financial situation. The CCEJ, having examined the accounts of the city for the previous five years, had concluded that the government was capable of implementing the new accounting system and that the relevant authorities should adopt double-entry bookkeeping. Soon afterward, Mayor Won accepted this recommendation (Lee, 2003).

Many people believe that the introduction of the new system was successful in the both cases of Bucheon and Gangnam-gu. Interestingly, from the standpoint of feasibility of the reform, the transition to the new system went smoothly and did not cause much trouble, which was considered evidence of success. This transition was made possible by the Local Government Accounting and Double-Entry Booking Information System (LADI), which was developed during the pilot project. This electronically-based accounting information system automated a large part of the process and facilitated the budgeting and accounting reforms of local governments. It also removed one of biggest barriers to budgeting and accounting reforms, namely, those associated with training the public servants who are directly responsible for accounting tasks. LADI allowed the accounting information of double-entry bookkeeping to be produced automatically, thus making an in-depth understanding of double-entry book-keeping accounting principles unnecessary for low-level staff (Moon, 2003). According to a survey in which 35 members of the accounting staff of the Bucheon government were asked about their perception of LADI, $74.3 \%$ of them responded positively or strongly positively on its use, thus underscoring the benefits of the program for the rapid adoption of the double-entry system (Kang, 2003).

As of January 2002, all departments within the Bucheon City government began 
using the new accounting system, and the government started to produce financial statements based on double-entry bookkeeping and accrual basis accounting. In April 2003, the case of Bucheon's implementation of this new system was presented at an academic conference organized by the Comparative International Governmental Accounting Research group. By October 2003, Bucheon had succeeded in consolidating financial statements that covered general accounts, special accounts, public enterprises, trust funds, and other relevant transactions. Since then, Bucheon has earned a reputation for being strongly committed to producing consolidated financial statements.

Table 2. Timetable of the Adoption of the Double-Entry Bookkeeping and Accrual basis Accounting System in Bucheon

\begin{tabular}{c|l}
\hline Year & \multicolumn{1}{c}{ Process } \\
\hline $1998-1999$ & $\begin{array}{l}\text { local government examines the double-entry bookkeeping and accrual } \\
\text { basis accounting system local government discusses the double-entry } \\
\text { book-keeping and accrual basis accounting system with the Ministry of } \\
\text { Public Administration and Security local government notifies Ministry } \\
\text { of Public Administration and Security of its intention to adopt the dou- } \\
\text { ble-entry bookkeeping and accrual basis accounting system }\end{array}$ \\
\hline January 2002 & $\begin{array}{l}\text { the double-entry bookkeeping and accrual basis accounting system is } \\
\text { adopted by all departments }\end{array}$ \\
\hline August 2002 & financial statements for year 2001 are published \\
\hline October 2003 2003 & $\begin{array}{l}\text { Bucheon's adoption of the system is reported at an academic confer- } \\
\text { ence of the Comparative International Governmental Accounting Re- } \\
\text { search network }\end{array}$ \\
\hline
\end{tabular}

One of the peculiarities of these reforms when compared with other administrative reforms undertaken by the Korean government is that they started as an experiment and were adopted in a gradual, stepwise way. Korean government leaders are often criticized for their tendency to implement reform measures in an "all at once" fashion (Im, 2010). The pilot-study method used in Bucheon was thus exceptional because the new system was pretested before being applied to the entire nation.

The positive response to the pilot tests in Bucheon and Gangnam-gu encouraged the reformers of the central government to extend the experiment to more local and 
provincial governments in January $2003 .^{2}$ Also, at this time accounting standards and the computer system were standardized and deployed in each new pilot city.

While Kim Dae-jung government set the experimental reform of the accounting system in motion, the successor government of President Roh Moo-hyun government identified itself as fundamentally innovative and made the task of completely overhauling local governmental systems a presidential priority. In April in 2003, the adoption of the double-entry bookkeeping and accrual basis accounting system was included in the reform agenda for decentralization and finance and tax reforms outlined by the Presidential Committee on Government Innovation and Decentralization. Yun Sung-sik, a CPA, actively participated at this stage and became the chair of this committee. In December 2003, the Special Act for Decentralization was legislated, according to which local governments were required to adopt the double-entry bookkeeping system (RYU \& Kwon, 2007). Again, strong political support at the presidential level played an important role in this generalization of the reform to all the local governments.

On April 30, 2004, the 10th Accounting Standards Committee for Local Governments developed accounting standards for local governments based on the double-entry bookkeeping and accrual basis accounting system after examining the accounting standards used in pilot projects and taking foreign examples into account. In September 2004, a public hearing was held to collect expert and public opinions on the accounting standards for local governments. In November that year, the Ministry of Public Administration and Security selected 54 other local governments on top of the existing 9 for pilot projects (Jung, Y. H., 2006).

This final decisive move toward the adoption of the new system was undertaken by the National Assembly. The revision of Local Finance Act in June 2005 clearly stated that all the local governments were obligated to produce financial statements based on the double-entry bookkeeping and accrual basis accounting system starting in 2007. As a result, all the local governments adopted this system in 2007 and have been using an electronic local financial management system (i.e., e-Hojo) since January 2008.

2. The following local governments were encouraged to conduct this experiment: Seo-gu District in Daejeon Metropolitan City, Jeonju City, Jeongeup City, Muju County, Sunchang County, and Jeonbuk Province. 


\section{EFFECTS OF THE REFORMS}

\section{Goals}

Uniformity, accuracy, consistency, and accountability are the aim of financial management and the accounting system as an organization pursues its goals, and it was no different in the reform attempted by the Korean government. The impetus for adopting double-entry bookkeeping based on accrual basis accounting for local governments in Korea was that it would make it possible to gain a thorough understanding of the overall financial position of a particular district at a given time. This is because double-entry accounting provides a better way to record changes in overall assets (see appendix 1 for an overview of single- versus double-entry bookkeeping), while an accrual basis accounting system offers a better way to record income and expenses, namely, at the time income is earned and at the time expenses are incurred, as opposed to income being logged when it is received and expenses when they are paid, which is how it is done in a cash basis system (see appendix 2). The knowledge offered by double-entry bookkeeping based on accrual basis accounting would, it was hoped, enable a more holistic management of assets, liabilities, and net assets and thereby lead to cost management and facilitate performance measurement and business analysis. It was also hoped that the new system would enhance the accountability of public finance and make it possible to understand annual asset acquisition at a deeper level. These were the reformers' goals when they pushed for change, and they continue to be attractive possibilities.

\section{Effects}

The result of the reform effort was the widespread implementation of double-entry bookkeeping and accrual basis accounting. However, it is still early to accurately evaluate the real and long-term effects of these new accounting processes. Based on the case of Bucheon, whose reform has a longer timeline, we try to evaluate the effects of the reform, but it must be noted that these effects cannot be characterized as a general outcome of the reforms but only as specific to Bucheon.

\section{Comprehensiveness}

The financial statements produced after the adoption of double-entry bookkeeping and the accrual basis accounting system document the financial position of Bucheon, the nature of its financial operation, the change in its net assets, and its 
cash flows. Among these, the statement of financial position and the statement of financial operation offer much richer accounting information than those produced under the previous system. We here provide details as to the type and quality of information gained by the new techniques.

\section{Provision of Information about Financial Position}

The statement of financial position discloses the financial situation at a given time (in this case, 2009) and consists of a record of assets, liabilities, and net assets. According to Bucheon's 2009 statement of financial position, total assets were ¥9,745,377 million, total liability was $\$ 171,805$ million, and net assets, which is total assets minus total liability, were $\$ 9,573,572$ million. Net assets are the resources that Bucheon has at its disposal to provide public services in the future. The volume of net assets is larger than that of liabilities, which is accounted for by the differences between local governments and private companies. The total financial situation is further divided up into accounts.

First, cash assets consisted of $\$ 446,851$ million (4.59\%) and noncash assets of \#9,298,526 million (95.41\%). These figures show that the proportion of noncash to cash assets is relatively large. Noncash assets consist of investments of 100,687 million (1.03\%), general tangible assets of $¥ 1,018,267$ million(10.45\%), residential facilities of $¥ 1,677,294$ million (17.21\%), social infrastructure of $¥ 6,495,695$ million(66.65\%), and other noncash assets of $\$ 6,583$ million KRW (0.07\%). Second, liabilities consist of a cash liability of $\$ 39,116$ million(22.77\%), a long-term liability of \#113,578 million (66.11\%), and other noncash liabilities of $\$ 19,111$ million(11.12\%), the portion of noncash liabilities being $77.23 \%$.

These figures highlight how double-entry bookkeeping and accrual basis accounting can accurately capture a city's financial situation. The adoption of double-entry bookkeeping and accrual basis accounting made it possible to analyze the financial situation at a given time by providing financial information about cash and noncash assets and cash and noncash liabilities, the latter being essential to understanding the position which a given government entity may occupy in the future. 
Table 3. Statement of Financial Position, December 31, 2009 (in million

\begin{tabular}{|c|c|c|c|c|c|c|c|}
\hline \multicolumn{2}{|c|}{ Items } & \multirow{2}{*}{$\begin{array}{c}\text { General } \\
192,530\end{array}$} & \multirow{2}{*}{$\begin{array}{l}\text { Special } \\
144,414\end{array}$} & \multirow{2}{*}{$\begin{array}{c}\begin{array}{c}\text { Trust } \\
\text { Funds }\end{array} \\
30,931 \\
\end{array}$} & \multirow{2}{*}{$\begin{array}{c}\begin{array}{c}\text { Public En- } \\
\text { terprises }\end{array} \\
87,255 \\
\end{array}$} & \multirow{2}{*}{$\begin{array}{c}\begin{array}{c}\text { Internal } \\
\text { Transactions }\end{array} \\
(8,280)\end{array}$} & \multirow{2}{*}{$\begin{array}{c}\text { Total } \\
446,851\end{array}$} \\
\hline & cash assets & & & & & & \\
\hline & investments & 102,119 & 928,478 & 111,416 & 37,620 & $(151,396)$ & 100,687 \\
\hline & $\begin{array}{l}\text { general } \\
\text { tangible assets }\end{array}$ & 992,486 & 13,872 & 1 & 11,908 & & $1,018,267$ \\
\hline \multirow[t]{3}{*}{ Assets } & $\begin{array}{l}\text { Residential } \\
\text { facilities }\end{array}$ & $1,537,294$ & 134,000 & & & & $1,677,294$ \\
\hline & \begin{tabular}{|l} 
Social \\
infrastructure
\end{tabular} & $5,217,471$ & 352,663 & & 925,560 & & $6,495,695$ \\
\hline & $\begin{array}{l}\text { Other non- } \\
\text { cash assets }\end{array}$ & 5,450 & 35 & & 1,048 & & 6,583 \\
\hline \multicolumn{2}{|c|}{ Total assets } & $8,047,401$ & 651,912 & 142,348 & $1,063,391$ & $(159,676)$ & $9,745,377$ \\
\hline \multirow{3}{*}{ Liabilities } & cash liabilities & 30,815 & 638 & 8,048 & 12,663 & $(13,048)$ & 39,116 \\
\hline & $\begin{array}{l}\text { long-term } \\
\text { liabilities }\end{array}$ & 152,109 & 10,000 & 63,005 & 5,378 & $(116,914)$ & 113,578 \\
\hline & $\begin{array}{l}\text { other noncash } \\
\text { liabilities }\end{array}$ & 17,755 & 24 & & 1,332 & & 19,111 \\
\hline \multicolumn{2}{|c|}{ Total liabilities } & 260,266 & 1,560 & 59,533 & 29,539 & $(118,442)$ & 171,805 \\
\hline \multirow{3}{*}{ Net Assets } & fixed net assets & $7,635,863$ & 496,570 & 1 & 930,994 & & $9,063,428$ \\
\hline & $\begin{array}{l}\text { special net } \\
\text { assets }\end{array}$ & & & 71,293 & & & 71,293 \\
\hline & $\begin{array}{l}\text { general net } \\
\text { assets }\end{array}$ & 210,859 & 144,680 & & 113,025 & $(29,713)$ & 438,850 \\
\hline \multicolumn{2}{|c|}{ Total Net Assets } & $7,846,772$ & 641,250 & 71,295 & $1,044,018$ & $(29,713)$ & $9,573,572$ \\
\hline \multicolumn{2}{|c|}{$\begin{array}{l}\text { Total Liabilities and Net } \\
\text { Assets }\end{array}$} & $8,047,401$ & 651,912 & 142,348 & $1,063,391$ & $(159,676)$ & $9,745,377$ \\
\hline
\end{tabular}

\section{Provision of Information about Financial Operation}

According to the statement of financial operation, the total expenditure of Bucheon in the fiscal year 2009 was $\$ 802,200$ million, total revenues were \#1,030,233 million, and the balance was $\$ 228,033$ million, which is equal to total revenue minus total expense. Details of the result of financial operations are as follows. Expenditures consisted of social welfare expenses of 255,907 million(30.90\%), environmental protection expenses of 146,090 million(18.21\%), and transport and traffic expenses of $\$ 70,270$ million(8.76\%). Revenues consisted 
of internal revenue of $\$ 484,407$ million (47.02\%), intergovernmental transfer revenue of $\$ 537,409$ million (52.16\%), and other revenues of $\$ 8,418$ million $(0.82 \%)$. The portion of intergovernmental transfer revenue is thus relatively high. The documentation of the financial performance for the fiscal year that the new accounting system enables thus provides more systematic information about the government revenue and expenditure than the old system.

Table 4. Statement of Financial Operation (by Functions), from January 1, 2009, to December 31, 2009 (in million

\begin{tabular}{|c|c|c|c|c|c|c|c|}
\hline & & General & Special & $\begin{array}{l}\text { Trust } \\
\text { Funds }\end{array}$ & $\begin{array}{c}\text { Public } \\
\text { Enterprises }\end{array}$ & $\begin{array}{c}\text { Internal } \\
\text { Transactions' }\end{array}$ & Total \\
\hline \multirow{14}{*}{ Expenditure } & $\begin{array}{l}\text { general public } \\
\text { administration }\end{array}$ & 42,216 & 141 & 1,990 & & $(4,734)$ & 39,612 \\
\hline & $\begin{array}{l}\text { public order and } \\
\text { safety }\end{array}$ & 4,405 & & 21 & & $(100)$ & 4,326 \\
\hline & Education & 14,868 & & & & & 14,868 \\
\hline & $\begin{array}{l}\text { culture and } \\
\text { tourism }\end{array}$ & 50,333 & & 360 & & (200) & 50,493 \\
\hline & $\begin{array}{l}\text { environmental } \\
\text { protection }\end{array}$ & 50,010 & & 178 & 96,403 & $(501)$ & 146,090 \\
\hline & social welfare & 254,953 & 3,849 & 456 & & $(3,352)$ & 255,907 \\
\hline & Health & 11,033 & & 250 & & & 11,283 \\
\hline & $\begin{array}{l}\text { agriculture and } \\
\text { fishing }\end{array}$ & 3,439 & & & & & 3,439 \\
\hline & $\begin{array}{l}\text { industry and small } \\
\text { business }\end{array}$ & 23,621 & & 622 & & $(4,090)$ & 20,154 \\
\hline & $\begin{array}{l}\text { transportation and } \\
\text { traffic }\end{array}$ & 104,712 & 19,541 & & & $(53,983)$ & 70,270 \\
\hline & $\begin{array}{l}\text { religious and } \\
\text { other community } \\
\text { development }\end{array}$ & 23,089 & 338 & & & $(600)$ & 22,828 \\
\hline & $\begin{array}{l}\text { science and } \\
\text { technology }\end{array}$ & & & & & & \\
\hline & $\begin{array}{l}\text { contingency } \\
\text { allowance }\end{array}$ & & & & & & \\
\hline & Other & 156,950 & 4,910 & 1,069 & & & 162,929 \\
\hline \multicolumn{2}{|c|}{ Total Expenditure } & 739,629 & 28,779 & 4,949 & 96,403 & $(67,560)$ & 802,200 \\
\hline \multirow{3}{*}{ Revenues } & Internal & 361,073 & 33,293 & 6,159 & 87,656 & $(3,773)$ & 484,407 \\
\hline & $\begin{array}{l}\text { intergovernmental } \\
\text { transfer }\end{array}$ & 406,674 & 130,462 & 61 & 211 & & 537,409 \\
\hline & Other & 3,484 & 63,489 & 1,901 & 480 & $(60,936)$ & 8,418 \\
\hline \multicolumn{2}{|c|}{ Total Revenues } & 771,230 & 227,244 & 8,121 & 88,347 & $(64,710)$ & $1,030,233$ \\
\hline \multicolumn{2}{|l|}{ Balance } & 31,601 & 198,456 & 3,173 & $(8,056)$ & 2,851 & 228,033 \\
\hline
\end{tabular}




\section{Accountability}

The statements of financial position and financial operation, along with daily, monthly, quarterly, semiannual and annual reports, document taxes that local governments levy and other received revenues. This makes it possible for a financial director to search receivables (tax receivables and taxes in arrears) and revenues in the year and the previous year without extra effort and thus improves the management of tax in arrears and revenues.

Table 5. Tax Receivables and Allowances for Tax Receivables in Arrears (in million $\#$ )

\begin{tabular}{|c|c|c|c|c|c|}
\hline & assification & $\begin{array}{l}\text { Amount of Re- } \\
\text { ceivables (A) }\end{array}$ & $\begin{array}{l}\text { Rate of Allow- } \\
\text { ance for Tax } \\
\text { Receivables in }\end{array}$ & $\begin{array}{l}\text { Amount of Al- } \\
\text { lowance for } \\
\text { Tax Receivables }\end{array}$ & $\begin{array}{l}\text { Book Value } \\
\text { (A-B) }\end{array}$ \\
\hline & residence tax & $20,888,753,920$ & 40.51 & $8,462,034,213$ & $12,426,719,707$ \\
\hline & property tax & $4,951,242,760$ & 9.13 & $452,048,464$ & $4,499,194,296$ \\
\hline $\begin{array}{l}\text { Standard } \\
\text { Taxes }\end{array}$ & car tax & $11,800,442,610$ & 19.98 & $2,357,728,433$ & $9,442,714,177$ \\
\hline & integrated land tax & $437,897,940$ & 21.92 & $95,987,229$ & $341,910,711$ \\
\hline & Sum & $38,078,337,230$ & & $11,367,798,339$ & $26,710,538,891$ \\
\hline & urban planning tax & $2,584,090,130$ & 9.59 & $247,814,244$ & $2,336,275,886$ \\
\hline Special & office tax & $120,294,360$ & 22.71 & $27,318,850$ & $82,975,510$ \\
\hline Taxes & public facilities tax & 373,680 & 1.0 & 3,737 & 369,943 \\
\hline & Sum & $2,704,758,170$ & & $275,136,831$ & 2,429,621,339 \\
\hline Total & & $40,783,059,400$ & & $11,642,935,170$ & $29,140,160,230$ \\
\hline
\end{tabular}




\section{Various Financial Analyses according to Account Settlement}

In the budgetary accounting of the past, the formula of balance equals budget minus expenditure was used to settle accounts. Needless to say, such a simple financial analysis is limited and cannot provide a complete picture of the financial position of local governments. Local governments that have adopted the modern method of accounting outlined in this paper are able to measure and evaluate not only financial health but also the efficiency and flexibility of their operations. Such measurements reflect the attributes of local government as nonprofit entities. Also, it is possible to take advantage of the analysis in ways that can reveal the symptoms of an impending financial crisis. This is an attractive tool for a country that experiences financial stress from time to time.

The financial analysis shows performance indicators for the following three areas: financial position, financial operation, and accounting accountability. A picture of these indicators would not have been possible if not for the financial statements that were based in accrual basis accounting. An overview of these indicators is presented in table 6 .

Table 6. Indicators for Financial Analysis

\begin{tabular}{|c|c|c|}
\hline Types & Indicators & Formula \\
\hline \multirow{9}{*}{$\begin{array}{l}\text { Financial } \\
\text { Position }\end{array}$} & ratio of total liabilities to total assets & total liabilities / total assets $\times 100$ \\
\hline & ratio of borrowing liabilities to total liabilities & borrowing liabilities / total liabilities $\times 100$ \\
\hline & ratio of real liabilities to total liabilities & real liabilities / total liabilities $\times 100$ \\
\hline & ratio of financial products to financial funds & financial products / financial funds $\times 100$ \\
\hline & $\begin{array}{l}\text { ratio of cash-generating assets to total } \\
\text { liabilities }\end{array}$ & cash-generating assets / total liabilities $\times 100$ \\
\hline & ratio financial funds to borrowing liabilities & financial funds / borrowing liabilities $\times 100$ \\
\hline & ratio of cash liabilities to cash assets & cash liabilities / Cash assets $\times 100$ \\
\hline & $\begin{array}{l}\text { ratio of allowances for tax receivables in } \\
\text { arrears to tax receivables }\end{array}$ & $\begin{array}{l}\text { allowances for tax receivables in arrears } / \\
\text { tax receivables } \times 100\end{array}$ \\
\hline & $\begin{array}{l}\text { ratio of short-term private loans to short-term } \\
\text { and long-term private loans }\end{array}$ & $\begin{array}{l}\text { short-term private loans / short-term and } \\
\text { long-term private loans } \times 100\end{array}$ \\
\hline
\end{tabular}




\begin{tabular}{|c|c|c|}
\hline Types & Indicators & Formula \\
\hline \multirow{9}{*}{$\begin{array}{l}\text { Financial } \\
\text { Operation }\end{array}$} & rate of expenditure to budget & $\begin{array}{l}\text { expenditure (general funds }+ \text { special funds) } / \\
\text { budget(general funds }+ \text { special funds) } \times 100\end{array}$ \\
\hline & $\begin{array}{l}\text { rate of interest expense to administrative } \\
\text { expense }\end{array}$ & $\begin{array}{l}\text { interest expense / administrative expense } \times \\
100\end{array}$ \\
\hline & rate of interest expense to interest revenue & interest expense / interest revenue $\times 100$ \\
\hline & $\begin{array}{l}\text { rate of administrative revenue to total } \\
\text { revenue }\end{array}$ & administrative revenue / total revenue $\times 100$ \\
\hline & $\begin{array}{l}\text { rate of self-raised administrative revenue to } \\
\text { administrative revenue }\end{array}$ & $\begin{array}{l}\text { self-raised administrative revenue/ } \\
\text { administrative revenue } \times 100\end{array}$ \\
\hline & rate of receivables to self-raised revenue & receivables / self-raised revenue $\times 100$ \\
\hline & rate of receivables to nontax revenue & receivables /nontax revenue $\times 100$ \\
\hline & $\begin{array}{l}\text { rate of administrative expense to total } \\
\text { expense }\end{array}$ & administrative expense / total expense $\times 100$ \\
\hline & $\begin{array}{l}\text { rate of expenditure for assets acquisition to } \\
\text { expenditure }\end{array}$ & $\begin{array}{l}\text { expenditure for assets acquisition / } \\
\text { expenditure } \times 100\end{array}$ \\
\hline \multirow{11}{*}{$\begin{array}{l}\text { Accounting } \\
\text { Responsi- } \\
\text { bilities }\end{array}$} & total assets per capita (residents) & total assets / number of residents \\
\hline & total liabilities per capita (residents) & total liabilities / number of residents \\
\hline & real liabilities per capita (residents) & real liabilities / number of residents \\
\hline & total revenues per capita (residents) & total revenues / number of residents \\
\hline & self-raised revenue per capita (residents) & self-raised revenue / number of residents \\
\hline & local tax revenue per capita (residents) & local tax revenue / number of residents \\
\hline & total expense per capita (residents) & total expenses / number of residents \\
\hline & $\begin{array}{l}\text { private transfer expense per capita } \\
\text { (residents) }\end{array}$ & $\begin{array}{l}\text { private transfer expense / number of } \\
\text { residents }\end{array}$ \\
\hline & total revenue per capita (civil servants) & total revenue / number of civil servants \\
\hline & total expenses per capita (civil servants) & total expenses / number of civil servants \\
\hline & total wages per capita (civil servants) & total wages / number of civil servants \\
\hline
\end{tabular}


In addition to providing analytical benefits, the in-depth financial statements made possible by accrual basis accounting also makes the comparative analysis of cities and districts also much easier, thus giving us a sense not only of a government's performance in isolation but also relative to similar cities.

\section{CONCLUDING REMARKS}

The case study of Bucheon sheds light on the process of transitioning to a new accounting system in order to rectify problems associated with the old system. The initial effects of the double-entry accrual basis accounting system have been widely perceived as positive insofar as financial information about the public sector and its agencies is now much more robust; however, it is not known whether the transition has produced an entirely new paradigm of budget and financial management or whether the Republic of Korea has fixed the problem of waste or corruption due to the new system.

Unlike other administrative reforms introduced by the Korean government, the Bucheon pilot project was carried out for five years before the reforms were fully rolled out to other sectors. Many key stakeholders and relevant actors, including presidents and mayors, have shown consistent support for the reform agenda. After the reforms were first introduced, it was another three years before the Local Finance Law was revised to require all local governments in the nation to adopt the new system. This long-term and step-by-step approach directly contrasts with the usual quick and dirty reform style of the Korean government (Im, 2009). The government's cautious and incremental approach of proceeding with the reforms does not necessarily mean that these reformers were fundamentally different from their predecessors. Rather, it highlights the fact that the reform itself was considered risky in nature. In other words, this reform targeted and entrenched and central element of the nation's bureaucracy, and the recognition of this fact was one of the underlying reasons the reformers took a more cautious approach in its implementation.

How was it possible to overcome bureaucrats' general resistance to reform? The invention of the LADI software, which facilitated the task of inputting financial transactions into the new system, helped minimize resistance. The reform went beyond the mere adoption of new technology, and instead changed the institutionalized routine and work behavior of civil servants. This fact, however, raises an important question: if the reform can change only the behavior of civil servants without also transforming their way of thinking, then aren't the reforms superficial 
in nature, regardless of the technical achievement of implementing the system? Thus, it remains to be seen whether the reforms will turn out to be successful in preventing the abuse of the local government's financial discretion or only force those who may still have incentives to conceal financial problems to adjust to the new system.

Thus, although there have been positive perception on the reform, it is hard to say just yet whether the reforms have resolved all existing problems, such as lack of transparency and inefficiency in budgeting, just to name a couple. These persistence of these problems, which has been observed in other countries where similar systems have been implemented, implies that the double-entry system, in its present form, does not in itself guarantee complete success in Korea. In other words, while new technology can produce transformative effects when used by individuals motivated by the benefits that transformation can bring, it is these very individuals who represent the key variable and not the technical tool itself; the success of the reform ultimately rests on them.

The introduction of a foreign institution into a domestic system can be likened not to the application of watercolor paints to a blank canvas but rather to the application of oil paints over an already existing painting. Beneath the new coat of paint is a complete picture that has historical precedence, and therefore we suggest that it is necessary to take the heritage of the South Korean government accounting system into account if new accounting system is to be used to its greatest advantage. This might be accomplished by defining accounting categories that reflect the existing activities of the government sector and connecting these new categories with budget categories. The goal of the new accounting system was to increase government performance and transparency. However, the new accounting system was not a sufficient but rather a necessary condition for increasing the Korean government's competitiveness. New accounting systems can provide good material (performance information) with which to build a house, but they cannot become the house itself. The government had not expected the new accounting system to be a panacea in the first place, but subsequently, introducing the system became the goal itself, and the government left behind the initial goal of improving its performance. Improving government performance and government competitiveness with the double-entry bookkeeping and accrual basis accounting system must be linked with reform of the budgeting and performance evaluation system (Im \& Hartley, 2017). Changing the mindsets of officials is a critical condition of seeing the full effect of the reform.

Although automated software has greatly eased the transition to double-entry accounting, the presence of independent external auditors who could strictly and accurately audit the accounts of localities would both expose weaknesses in current 
accounting practices as well as increase the transparency of government operations and thus public trust in them. This is a practice that has long been used in Anglo-Saxon countries, where professional accountants are employed in the public sector for government accounting. In the UK, the Chartered Institute of Public Finance Accountancy trains experts for public sector accounting. It confers certificates of chartered public finance accountant to qualified candidates, who then go on to work for governments (Hur, 2003, p. 72). In the United States, the Association of Government Accounts trains certified government financial managers. Similar measures might be taken in Korea to strengthen the Korea Institute of Certified Public Accountants.

Therefore, it is necessary to better train not only the accountants who produce the accounting reports but also the local council members who make decisions based on these reports. Reports produced by double-entry accrual basis accounting are useful in revealing areas where governments can improve their financial management. However, because of this power they are also significantly more complex. Government watch groups have repeatedly criticized the low capacity of public servants who deal with such reports, and Bucheon has responded by running accounting education programs to improve the skills of public servants in local councils. Nevertheless, considering that the term of council members is four years, it is recommended that such programs themselves be reinforced and improved so that localities will have the continuous benefit of well-trained, competent council members.

\section{REFERENCES}

Ho, A.T., \& Im, T. 2012. Defining a new concept of government competitiveness. Korea Journal of Public Administration, 50(3): 1-34.

Hood, C. 1991. A public management for all seasons? Public Administration, 69(1): 1-19.

Hood, C. 1995. The "new public management" in the 1980s: Variations on a theme. Accounting, Organizations and Society, 20(2): 93-109.

Hur, M. S. 2003. Accounting reform and charted public finance and accountants in the UK. Government Accounting Research, 1(1): 63-76.

Im, T. 2007. Bureaucracy, democracy, and market. Korean Public Administration Review. 41(3): 41-65

Im, T. 2009. The case for the Korean bureaucracy. Korean Review of Organizational Studies, 6(3): 173-209. 
Im, T. 2010. A critical review of new public management reform in Korean government. Korean Society and Public Administration, 21(3):1-27

Im, T., \& Hartley, K. 2017. Aligning needs and capacities to boost government competitiveness. Public Organizations Review. DOI 10.1007/s11115-017-0388-0.

Jo, S. E. 2003. Research on the process of accounting reforms in South Korean local governments. Masters' thesis, Seoul National University.

Jung, Y. D. 2004. Governance and government policies in the era of globalization. Seoul: Pakyoungsa.

Jung, Y. H. 2006. Achievements and tasks of accrual basis accounting system in local government. 2006 spring academic conference paper, the Korean Association for Government Accounting.

Kang, I. J. 2003. Reforming accounting processes in local governments. 2003 winter academic conference paper, the Korean Association for Government Accounting.

Lee, N. K. 2003. Governmental accounting reform: An application of Lüder's “contingency model." Korean Public Administration Review, 37(4): 193-213.

Lim, D. 2007. A comparative study of the institutionalization of double-entry bookkeeping and accrual accounting system in central governments of OECD member countries. Korean Public Administration Review, 41(1): 129-151.

Lim, D., \& Jong, Y. 2007. A comparative study of the institutionalization of the accrual accounting system in the United Kingdom and the United States. Korean Journal of Policy Studies, 21(2): 75-99.

Moon, B. G. 2003. Review of accounting system reforms in Korean local governments: From AIA to LADI system. Government Accounting Research, 1(1): $1-25$.

OECD. 2017. Accrual practices and reform experiences in OECD countries.

Pollitt, C., \& Bouckaert, G. 2004. Public management reform: A comparative analysis. 2nd ed. New York: Oxford University Press.

Pyun, H. 2012. Personal recollections regarding government accounting. White paper, 10-year anniversary of the Korean Association for Government Accounting.

Ryu, S. Y \& Kwon. B. C. 2007. Introduction and Direction of Double-entry and Accrual Basis Accounting System in Government Sector. Government Accounting Research, 5(1): 47-70.

Scott, W. R. 1991. Unpacking institutional arguments, in P. Dimaggio \& W. W. Powell (eds.), The New Institutionalism in Organizational Analysis (pp. 164-182). Chicago: University of Chicago Press.

Yoon, S. S. (2003), Budgeting theories, Seoul: Nanam publications.

Yoon, Y. J. (2003), Public Budgeting and Financial Management, Seoul: Dae Young. 